\title{
Effects of superheated steam treatment on volatile compounds and quality characteristics of onion
}

\author{
Mi-Hyun Lee ${ }^{1}$, Kyo-Youn Lee ${ }^{1}$, Ahna Kim ${ }^{1}$, Ho-Jin Heo ${ }^{1}$, Hyun-Jin Kim ${ }^{1}$, \\ Ji-Yeon Chun ${ }^{3}$, Sung-Gil Choi ${ }^{2 *}$ \\ ${ }^{1}$ Division of Applied Life Science, Gyeongsang National University, Jinju 52828, Korea \\ ${ }^{2}$ Department of Food Science and Technology/Institute of Agriculture and Life Sciences Gyeongsang National University, \\ Jinju 52828, Korea \\ ${ }^{3}$ Department of Food Technology Sunchon National University, Sunchon 57922, Korea
}

\section{과열 증기 처리에 따른 양파의 향기 성분 및 품질특성}

\author{
이미현 ${ }^{1} \cdot$ 이교연 $^{1} \cdot$ 김아나 $^{1} \cdot$ 허호진 $^{1} \cdot$ 김현진 $^{1} \cdot$ 천지연 $^{3} \cdot$ 최성길 $^{2 *}$ \\ ${ }^{1}$ 경상대학교 응용생명과학부 응용생명과학전공, ${ }^{2}$ 경상대학교 식품공학과/농업생명과학연구원, \\ ${ }^{3}$ 순천대학교 식품공학과
}

\begin{abstract}
This study was conducted to investigate the effects of superheated steam (SHS) on volatile compounds and the quality characteristics of onion. Onion samples were treated by SHS at various steam temperatures $\left(100 \sim 300^{\circ} \mathrm{C}\right)$ for 1 min. Thiosulfinates and pyruvic acid were reduced by SHS treatment. The absorbance values obtained for thiosulfinates, the odor-causing compounds in onions, treated by were $0.889,0.085,0.049,0.049$, and 0.045 , while that of the untreated control sample was 1.587. The pyruvic acid contents of onions treated by SHS were 7.57, $5.85,1.66,0.47$, and $0.26 \mathrm{mg} / \mathrm{mL}$, while that of the untreated control sample was $8.00 \mathrm{mg} / \mathrm{mL}$. Volatile compounds such as, dipropyl trisufide, 1,3-propanedithiol, methyl thiirane, methyl propyl trisulfide, diallyl disulfide, 1-(methylthio)-1-propene, 1,1-thiobis-1-propene, 1,1-sulfinyl bispropane, dimethyl tetrasulfide, methyl propenyl disulfide, dimethyl trisulfide, and diallyl disulfide were reduced by SHS treatment. The results showed that antioxidant activities in the of onion samples were improved by SHS treatment. The hardness and chewiness of onions treated by SHS were significantly lower than those of the untreated control onion sample. Sensory evaluation suggested that SHS could help lower off-flavors in and enhance the palatability of onions. These results suggest that the application of SHS treatment to onions can decrease their off-flavors, change their textural attributes, and promote their sensory properties.
\end{abstract}

Key words : onion, reduction of off-flavor, super heated steam

\section{서 론}

양파(Allium cepa L.)는 백합과에 속하는 다년생 식물로

*Corresponding author. E-mail : sgchoi@gnu.ac.kr

Phone : 82-55-772-1906, Fax : 82-55-772-1909

Received 11 May 2016; Revised 10 June 2016; Accepted 22 June 2016.

Copyright (c) The Korean Society of Food Preservation. All rights reserved.
특유의 향미를 가지고 있어 식품의 조리 및 가공 과정에서 중요한 향신 조미료 소재로서 널리 이용되고 flavonoid (quercetin, rutin)와 황 화합물(Allyl propyl disulfide, diallyl disulfide)과 같은 phytochemical이 풍부하게 함유되어 있다 (1-3). 양파의 주된 flavonoid 성분인 quercetin은 벤젠환의 탄소에 $-\mathrm{OH}$ 기와 탄소의 1 과 2 사이의 이중결합, 3 의 탄소위 치에 carbonyl기, A고리와 B고리에 결합되어 있는 - $\mathrm{OH}$ 기에 의해서 항산화 활성을 갖는 구조를 지니고 있어 활성산소의 산화활동을 억제하거나 제거하는 능력이 매우 강하다(4) 
양파는 중금속 해독작용, 항균 및 항산화 작용 뿐 아니라 혈당저하, 항염증, 항천식성, 항암성과 같은 여러 가지 효과 가 보고되어 있다(5-9). 또한 양파는 양파세포가 파괴되었 을 때 allinase가 비휘발성 전구물질인 alliin을 분해하여 휘 발성 화합물인 allicin과 pyruvate, ammonia, thiosulfinate등 을 생성한다 $(10,11)$. 양파의 냄새는 너무 강해 식품가공에 서 선호하지 않아 유효성분인 황 함유 성분의 손실없이 불쾌취를 masking 할 수 있는 물질 및 방법을 찾는 연구가 활발히 진행되고 있다(12).

포화수증기를 $100^{\circ} \mathrm{C}$ 이상으로 가열하였을 때 생성되는 과열증기(superheated steam, SHS)는 $100 \sim 400^{\circ} \mathrm{C}$ 의 수증기 이며 고온의 스팀이 식품표면에 균일하게 분무되어 보다 짧은 시간 가열이 가능함과 동시에 증기를 재활용하기 때문 에 보다 에너지를 절약할 수 있는 가열방법이다. 일반적인 가열 시 발생하는 영양소 손실을 최소화 하고 식재료 고유 의 맛, 향, 색, 질감 등을 최대한 유지시키며 비타민 C 산화, 갈변 현상을 억제하고 미생물을 제어하는데 효과적인 것으 로 보고되고 있다(13-15). 과열증기는 주로 산업적으로 제 품의 건조나 저장 중 품질 유지를 위해 사용되어 왔으며, 또한 대류, 복사에 의한 높은 열전달로 식품의 조리시간을 단축시키고, 식품 자체에 함유되어 있는 나트륨을 고르게 분포시키는 장점이 있는 것으로 보고되고 있다(16-17). 과 열증기 처리는 한번의 공정에서 식품 불쾌취 탈취, 블랜칭, 저온살균, 멸균이 동시에 가능하고 식품에 존재하는 과도 한 지방과 염의 제거도 가능한 매우 효율적인 공정으로 알려져 있으나(18), 과열증기를 식품 가공에 접목한 국내 연구현황은 매우 미비한 상태이다.

따라서 본 연구에서는 과열증기 장치를 이용한 양파의 불쾌취 저감화 및 이를 통한 고품질 가공품 개발을 목적으 로 하는 기초 연구를 위해 과열증기처리 온도에 따른 양파 의 휘발성 물질, 불쾌취 유발 물질과 항산화활성, 조직감, 관능적 특성 등 품질특성을 조사하였다.

\section{재료 및 방법}

\section{실험 재료}

본 실험에 사용된 양파는 경상남도 창녕에서 2014년에 수확된 양파를 구매하여 사용하였다. 실험을 실시하기 전 양파를 과피와 과육으로 분리 후 양파의 과피는 흙이 모두 제거될 때 까지 그리고 과육은 흐르는 물에서 세척하고 물기를 제거한 후 실험에 사용하였다.

\section{과열 증기 처리}

과열증기 처리에 따른 양파의 이화학적 및 관능특성의 변화를 알아보기 위해 과열증기 처리한 조건은 Table 1 과 같다. 본 실험에 사용된 과열증기는 QF-5200C(Naomoto,
Osaka, Japan)을 사용하였다. 과열증기오븐의 구조는 Fig. 1 에 나타내었다. 내부온도, 스팀의 세기는 동일하게 하고, 스팀 온도는 각각 $100 ~ 300^{\circ} \mathrm{C}$ 범위에서 처리하였으며, 각 시료는 처리온도에 따라 T100, T150, T200, T250, T300으로 각각 명명하였다. 스팀의 노즐은 위 아래에 위치하게 하여 균일한 처리를 도모하였으며 상, 하로부터 배출되는 스팀 이 일정하게 양파 표면에 접촉할 수 있도록 하기 위해 노즐 위치를 $8 \mathrm{~cm}$ 로 동일하게 조절한 후 처리하였다.

Table 1. Superheated steam treatment (SHS) conditions for onion flesh

\begin{tabular}{ccccc}
\hline & Heater $\left({ }^{\circ} \mathrm{C}\right)$ & Steam $\left({ }^{\circ} \mathrm{C}\right)$ & $\begin{array}{c}\text { Heating time } \\
(\mathrm{min})\end{array}$ & $\begin{array}{c}\text { Degree of steam } \\
\left(\mathrm{m}^{3} / \mathrm{h}\right)\end{array}$ \\
\hline Control & - & - & - & - \\
T100 & 130 & 100 & 1 & 7.3 \\
T150 & 130 & 150 & 1 & 7.3 \\
T200 & 130 & 200 & 1 & 7.3 \\
T250 & 130 & 250 & 1 & 7.3 \\
T300 & 130 & 300 & 1 & 7.3 \\
\hline
\end{tabular}

양파의 휘발성 물질 분석

양파의 휘발성 물질의 분석을 위한 흡착은 SPME(Solid Phase Microextraction Fiber Holder, Supelco., Bellefonte, $\mathrm{PA}, \mathrm{USA})$ 는 $\mathrm{DVB} / \mathrm{CAR} / \mathrm{PDMS}(50 / 30 \mu \mathrm{m})$ 를 사용하여 전처 리하였다. 전처리한 양파 추출물 $0.5 \mathrm{~mL}$ 을 $20 \mathrm{~mL} \mathrm{EPA}$ vial에 넣은 후 PTFE/Silicon으로 capping 하였다. Internal standard는 n-Butylbenzene를 사용하였고 샘플과 함께 $1 \mu \mathrm{L}$ 첨가한 후 $\mathrm{SPME}$ needle을 vial내로 삽입한 후 $70^{\circ} \mathrm{C}$ 에서 30 분간 흡착 후 $\mathrm{GC} / \mathrm{MS}$ 분석에 이용하였다. GC/MS분석은 shimadzu gas chromatograph(GC2010 plus, Shimadzu, Japan) 을 사용하고 column은 DB-5ms(thickness: $0.25 \mu \mathrm{m}$, length: $30 \mathrm{~m}$, Diameter: $0.25 \mathrm{~mm}$ )를 사용하였다. $\mathrm{He}$ 은 carrier gas로 사용하고, column oven temperature $100^{\circ} \mathrm{C}$, injection temperature $200^{\circ} \mathrm{C}$, total flow $1.10 \mathrm{~mL} / \mathrm{min}$, total program time $37 \mathrm{~min}$ 으로 설정 후 분석을 실시하였다.

Thiosulfinate 및 Pyruvic acid 측정

양파의 불쾌취를 확인할 수 있는 thiosulfinate의 함량은 Kee과 Park(12)을 응용하여 진행하였다. 과열증기오븐 처 리 양파를 원심분리하여 얻은 상층액 $1 \mathrm{~mL}$ 을 $10 \mathrm{~mL}$ 정량 플라스크에 넣고 증류수로 정용 후 $5 \mathrm{~mL}$ 을 test tube에 취하 고 HPLC용 Hexane $10 \mathrm{~mL}$ 을 넣어 2분간 vortex 후 정치시켜 분리한 Hexane층을 $320 \mathrm{~nm}$ 의 흡광도에서 측정하여 thiosulfinate의 상대적인 양을 관찰하였다.

양파의 매운맛(pungency)의 지표물질로 측정이 가능한 Pyruvic acid의 함량은 Kim 등(19)를 응용하여 진행하였다. 즉, 양파의 상층액 $80 \mu \mathrm{L}$ 에 $0.0125 \% \mathrm{DNPH}(2,4$-dinitropheny- 


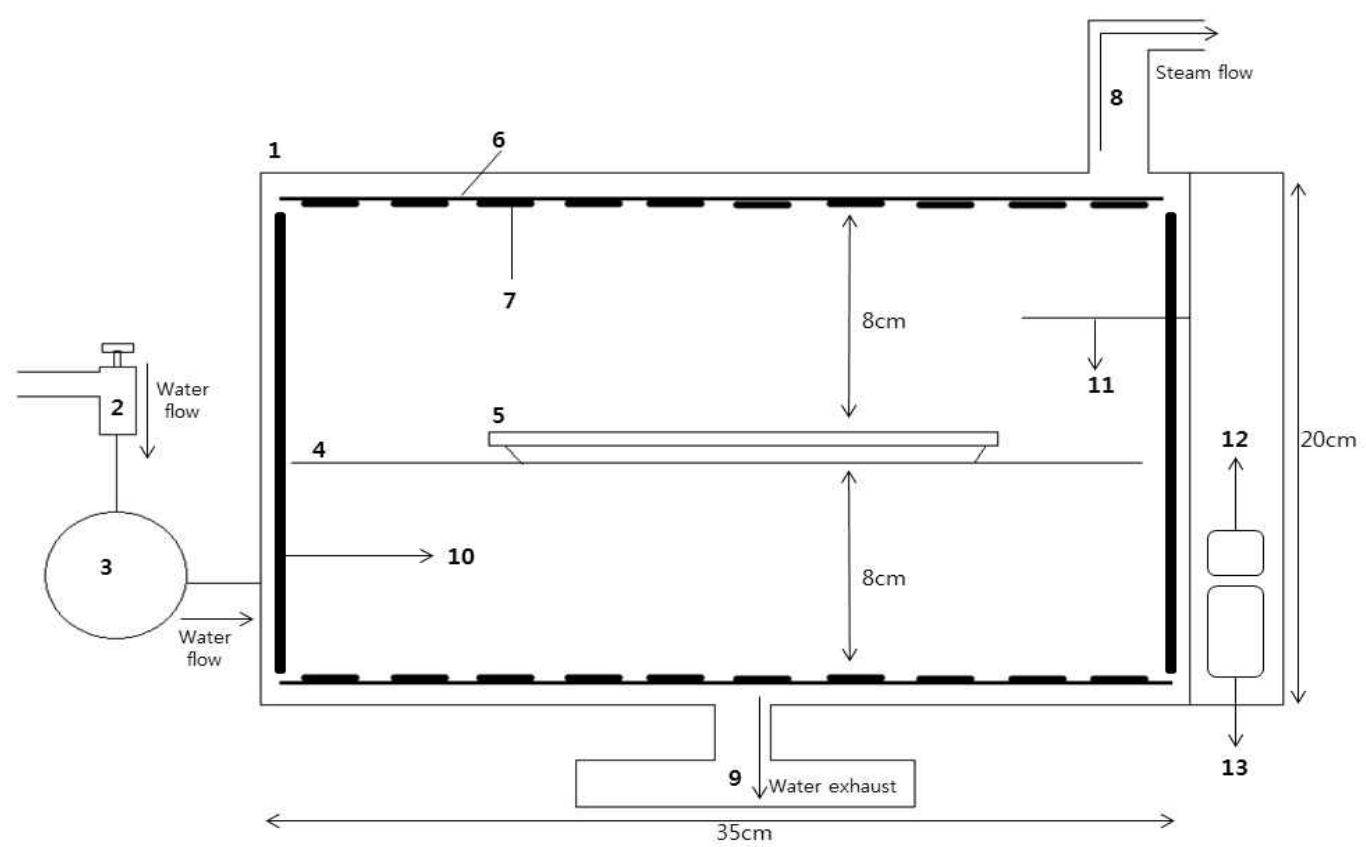

Fig. 1. A schematic diagram of the superheated steam machine.

1, chamber; 2, faucet; 3, softener (for removing calcium, magnesium, certain other metal cation in hard water); 4, tray; 5 , basket; 6 , heater; 7 , steam nozzle $\left(3.1 \sim 7.8 \mathrm{~m}^{2} / \mathrm{h}\right.$, $\left.100 \sim 400^{\circ} \mathrm{C}\right) ; 8$, air exhaust port; 9 , water exhaust port; 10 , heating panel $\left(\sim 300^{\circ} \mathrm{C}\right)$; 11 , heating wire; 12 , temperature controller; 13 , steam controller.

lhydrazine) $4 \mathrm{~mL}$ 을 넣고 진탕하여 $37^{\circ} \mathrm{C}$ 에서 10 분간 반응시 켰다. $0.6 \mathrm{~N} \mathrm{NaOH}$ 용액 $8 \mathrm{~mL}$ 을 첨가하여 $485 \mathrm{~nm}$ 에서 흡광 도를 측정하고 pyruvic acid 농도는 검량선을 이용하여 환산 하였다. 검 량선은 sodium pyruvate용액의 농도를 각각 2 , $4,6,8,10 \mathrm{mg} / \mathrm{mL}$ 로 하여 작성하였다.

\section{항산화활성 측정}

과열증기오븐 처리 양파의 항산화활성 측정은 quercetin 분석에 사용한 샘플을 적정량 취하여 사용하였다. $\mathrm{Fe}^{3+}$ (ferric)이 $\mathrm{Fe}^{2+}$ (ferrous)로 환원되는 원리(20)를 이용한 Ferric reducing/antioxidant power(FRAP)측정은 Foroogh 등(21)을 응용하여 실험을 진행하였다. 즉 $0.3 \mathrm{M}$ sodium acetate buffer(pH 3.6)와 $40 \mathrm{mM} \mathrm{HCl}$ 로 용해시킨 $10 \mathrm{mM}$ Tripydyltriazine(TPTZ), $20 \mathrm{mM} \mathrm{FeCl}{ }_{3} \cdot 6 \mathrm{H}_{2} \mathrm{O}$ 을 제조하였다. 미리 제조된 $0.3 \mathrm{M}$ Sodium acetate buffer, $10 \mathrm{mM}$ TPTZ, $20 \mathrm{mM} \mathrm{FeCl}_{3} \cdot 6 \mathrm{H}_{2} \mathrm{O}$ 을 10:1:1 (v/v/v) 비율로 혼합하여 FRAP 용액을 준비하였다. 그 후 원심 분리한 상층액 $50 \mu \mathrm{L}$ 와 FRAP $1.5 \mathrm{~mL}$ 을 혼합 후 실온 암실에서 30 분간 반응시킨 후 $593 \mathrm{~nm}$ 에서 흡광도를 측정하였다.

DPPH radical 소거활성은 Choi 등(22) 방법을 응용하여 실험을 진행하였다. 즉, $100 \mathrm{~mL}$ Ethanol에 $8 \mathrm{mg}$ 의 2,2 Diphenyl-1-picrylhydrazyl(DPPH)를 용해시켜 여과지로 여 과 후 흡광도가 $1.000 \pm 0.005$ 인 값으로 조정하여 $\mathrm{DPPH}$ 용액 을 제조한다. $\mathrm{DPPH}$ 용액 $0.9 \mathrm{~mL}$ 과 원심 분리한 상층액 $0.1 \mathrm{~mL}$ 을 혼합하여 실온 암실에서 30 분 반응 후 $517 \mathrm{~nm}$ 에서 흡광도를 측정하였다.
ABTS radical 소거활성은 Foroogh 등(21) 방법을 참고 및 수정하여 실험을 진행하였다. 즉, $7 \mathrm{mM} \mathrm{2,2-azinobis}$ (3-ethylbenzothiazoline-6-sulfonic acid) diammonium salt (ABTS) 와 $2.45 \mathrm{mM}$ potassium persulphate를 혼합 후 실온 암실에서 16 시간 방치 후 흡광도 값을 $0.700 \pm 0.005$ 로 조정 하여 $\mathrm{ABTS}(+)$ 를 제조한다. $\mathrm{ABTS}(+)$ 용액 $3.9 \mathrm{~mL}$ 과 원심분 리 상층액 $0.1 \mathrm{~mL}$ 을 혼합 후 6 분간 실온 암실에서 반응 후 $734 \mathrm{~nm}$ 에서 흡광도를 측정하였다.

\section{총 페놀 화합물 함량 측정}

총 페놀 화합물 함량 측정(Total phenolic contents, TPC) 은 $\operatorname{Kim}$ 등(23)의 방법을 참고 및 수정하여 실험을 진행하였 다. 즉, 원심분리 상층액 $1 \mathrm{~mL}$ 과 3 차 증류수 $9 \mathrm{~mL}$ 을 혼합 후 $1 \mathrm{~mL}$ 의 Folin \& Ciocalteaus' reagent를 첨가 후 실온 암실에서 5 분간 반응한다. 그 후 $7 \%$ sodium carbonate와 3 차 증류수 $4 \mathrm{~mL}$ 을 첨가한 후 실온 암실에서 2 시간 반응 후 $760 \mathrm{~nm}$ 에서 흡광도를 측정하였다. 표준곡선은 galic acid 를 표준물질로 $0.025,0.05,0.1,0.25,0.5,1 \mathrm{mg} / \mathrm{mL}$ 로 제조하 여 흡광도를 측정하였다.

\section{$\mathrm{pH}$ 및 $\mathrm{Brix}$ 측정}

과열증기오븐 처리 양파를 믹서기로 분쇄한 후 $\mathrm{pH}$ 와 Brix를 측정하였다. $\mathrm{pH}$ 는 $\mathrm{pH}$ meter(Model 735P, istek, Korea)을 사용하여 측정하였다. Brix는 Abbe refractometer (501-DS, ATAGO, Tokyo, Japan)로 측정하였다. 


\section{조직감(Texture) 측정}

과열증기오븐 처리한 양파의 조직감 측정은 texture analyzer(Stable micro systems, TA.XT Express, Godalming, $\mathrm{UK})$ 을 이용하여 텍스쳐 묘사 분석(Texture profile analysis, $\mathrm{TPA}$ )하였다. 양파 과육의 최외각 층을 가로, 세로, 각각 $4 \mathrm{~cm} \times 3 \mathrm{~cm}$ 의 크기로 맞추어 7회 반복하였다. 측정조건은 test speed $1.0 \mathrm{~mm} / \mathrm{sec}$ 로 $30 \mathrm{~mm}$ 까지 시료를 압착하는 조건 으로 측정하였다. 측정 후 얻어진 force time curve로부터 시료의 경도(hardness), 탄력성(springiness), 저작성(chewiness), 점착성(gumminess), 응집성(cohesiveness), 복원력(resilience) 을 산출하였다.

\section{총 가용성 고형분 함량}

$\operatorname{Kim}$ 등(24)의 방법을 응용하여 실험을 진행하였다. 즉, 양파를 8 등분한 후 $50 \mathrm{~mL}$ conical tube에 양파를 증류수와 첨가하여 $40,70,90^{\circ} \mathrm{C}$ 로 설정한 water bath에서 침지 및 가열하여 침출액을 제조하였다. Aluminum weighing dish에 침출액을 취해 $105^{\circ} \mathrm{C}$ 의 드라이오븐에서 항량에 이를 때까 지 건조한다. 건조 전과 후 중량 차이를 이용해 총 가용성 고형분 함량을 산출하였다.

\section{관능적 특성 평가}

증기온도를 다르게 한 과열증기오븐 처리 양파의 기호적 관능평가를 실시하였다. 관능평가 항목으로는 매운맛 (spicy), 외관(appearance), 향(flavor), 질감(texture) 및 전체 적인 기호도(overall acceptability)를 9점 척도법(1점 매우 싫다, 9점 매우 좋다)을 사용하여 경상대학교 식품공학과 학생 중에서 검사 방법 및 관능적 품질 특성에 대한 교육과 예비검사를 통해 선별한 학생 15 명을 대상으로 매운맛 등 의 정도를 판별하기 위한 트레이닝을 실시한 후 평가를 진행하였다. 시료는 제조 후 2시간 상온보관 후 실시하였고, 흰 종이컵에 $20 \mathrm{~g}$ 씩 담아 제시하였고 다음 시료 평가에 미치는 영향을 줄이기 위해 물을 함께 제공하였다.

\section{통계처리}

모든 실험 결과는 최소 3회 반복 실시 후 SAS program 9.1(Korea version)을 이용하여 ANOVA와 Duncan 분석을 수행하고, 평균값과 표준오차를 계산하였다. 시료간의 유 의적 차이를 알아보기 위하여 분산분석(analysis of variance, ANOVA)를 실시하였으며 시료간의 유의적 차이 가 나타나는 경우 Duncan's multiple range test를 수행하였 다 $(\mathrm{p}<0.05)$.

\section{결과 및 고찰}

양파의 휘발성 물질

양파의 휘발성 향기성분의 조성 및 함량의 분석 결과를
Table 2에 나타내었다. GC분석을 통해 비처리 대조군 양파 의 휘발성 향기성분에 기여하는 주요물질이 di-, tri- sulfide 류로 분석되었다. 3,5-Diethyl 1,2,4-Trithionlane이 3,264.95 $\mathrm{ng} / \mathrm{g}$ 으로 가장 높게 나타났고, 다음 Dipropyl trisufide (2,358.92 ng/g), 1,5-Dithiocane(1,179.51 ng/g), 1,3-Propanedithiol $(1,133.11 \mathrm{ng} / \mathrm{g})$, Methyl thiirane(475.11 ng/g), Methyl propyl trisulfide(436.79 ng/g), Diallyl disulphide(292.41 ng/g), 1-(methylthio) 1-Propene(281.69 ng/g), 1,1-thiobis-1-Propene (206.36 ng/g), 1,1-sulfinyl bis Propane(193.42 ng/g), Dimethyl tetrasulphide(184.04 ng/g), Methyl propenyl disulfide(153.90 $\mathrm{ng} / \mathrm{g}$ ), Dimethyl trisulfide(30.57 ng/g), Diallyl disulfide(6.96 $\mathrm{ng} / \mathrm{g}$ )의 순으로 높은 함량을 보였다. 지역별 양파종의 향기 성분을 비교한 Lee 등(25)의 연구에서도 주요 휘발성 물질 로 methylthiirane, methyl propyle disulfide, methyl propenyl disulfide, dimethyl trisulfede 등이 분석되었다. 또한, Dimethyl trisulfide, dimethyl tetrasulfide, 1-(methylthio)-1propene, dithiane은 각 다른 양파의 휘발성 성분 분석에서도 검출되어 이러한 성분들이 양파에 함유된 일반적인 향기성 분임을 확인하였다(10,26). 이중 Methyl thiirane, 1,1-sulfinyl bis Propane, Diallyl disulphide, 1,1-thiobis-1-Propene은 과열 증기처리군서는 전혀 검출되지 않았다. 다른 휘발성 물질 도 과열증기처리에 의해 전체적으로 크게 감소하였다. 양 파의 주요 불쾌취 성분으로 알려진 Dimethyl trisulfide는 $\mathrm{T} 150, \mathrm{~T} 200$ 을 제외한 모든 처리군에서 대부분 감소하는 것으로 나타났다. 흥미로운 점은 항균 및 항암 작용을 지니 는 것을 연구되고 있는 diallyl disulfide(10)은 T150과 T200 에서 각각 $5.34,3.48 \mathrm{ng} / \mathrm{g}$ 으로 크게 감소하지 않았다는 점이 다. 또한, 항산화활성을 가지는 것으로 알려진 3,5-Diethyl 1,2,4-Trithionlane(29)의 경우에도 T150(466.91 ng/g), T200 $(207.22 \mathrm{ng} / \mathrm{g})$ 에서 대조군에 비해 다소 감소하였지만 완전 히 소실되지는 않는 것으로 나타났다. 양파에는 다양한 생 리활성능을 지니는 성분도 많이 함유되어 있기 때문에 본 연구에 활용된 과열증기기술이 양파의 고품질 가공에 효과 적으로 적용되기 위해서는 불쾌취 저감화와 동시에 유용물

Table 2. Thiosulfinate \& Pyruvic acid contents of onion flesh treated by SHS at various temperature

\begin{tabular}{cccc}
\hline \multirow{2}{*}{ Control } & Thiosulfinate (absorbance) & $\begin{array}{c}\text { Pyruvic acid } \\
(\mathrm{mg} / \mathrm{mL})\end{array}$ \\
\hline & $\mathrm{T} 100$ & $1.587 \pm 0.005^{1) 22}$ & $8.000 \pm 0.000^{\mathrm{a}}$ \\
& $\mathrm{T} 150$ & $0.889 \pm 0.075^{\mathrm{b}}$ & $7.570 \pm 0.186^{\mathrm{b}}$ \\
SHS & $\mathrm{T} 200$ & $0.085 \pm 0.003^{\mathrm{c}}$ & $5.849 \pm 0.372^{\mathrm{c}}$ \\
treatment & T20 & $0.049 \pm 0.002^{\mathrm{d}}$ & $1.656 \pm 0.186^{\mathrm{d}}$ \\
& $\mathrm{T} 250$ & $0.049 \pm 0.002^{\mathrm{d}}$ & $0.473 \pm 0.186^{\mathrm{e}}$ \\
& $\mathrm{T} 300$ & $0.045 \pm 0.004^{\mathrm{d}}$ & $0.258 \pm 0.000^{\mathrm{e}}$ \\
\hline
\end{tabular}

${ }^{11}$ All measurements were performed in triplicate. Data was expressed as mean $\pm \mathrm{SD}$.

2)ae Different superscript in the same raw are significantly different by Duncan's multiple range test at $\mathrm{p}<0.05$. 
질의 감소를 최소화하는 것이 중요한 관건이며 이에 대한 추가적인 연구가 필요할 것으로 사료된다.

Thiosulfinate 및 pyruvic acid 함량

양파의 불쾌취를 확인할 수 있는 thiosulfinate의 결과는 Table 3에 나타내었다. 불쾌취 지표물질인 thiosulfinate의 측정 결과는 흡광도로 표시하며 그 수치가 높을수록 불쾌취 가 높은 것을 나타낸다. 대조구는 1.59 였고, 과열증기처리 에 의해 $100^{\circ} \mathrm{C}$ 온도에서 0.89 로 거의 $50 \%$ 에 가까운 감소를 보였고, 이를 제외한 $150 ~ 350^{\circ} \mathrm{C}$ 모두 아주 미미한 수치를 보여 거의 제거된 것으로 나타났다.

Pyruvic acid는 화학적으로 안정적이고 분석이 용이하여 양파의 pungency를 측정하는 방법으로 flavor를 측정하는
수단으로 이용된다 $(12,27)$. 과열증기처리에 따른 pyruvic acid 함량은 thiosulfinate의 측정결과와 유사한 경향을 나타 내는 것을 확인할 수 있었다. 한편, microwave 처리에 따른 pyruvic acid의 함량을 분석한 You와 Pike(33)의 연구에서 처리시간이 경과함에 따라 pyruvic acid 함량이 감소하는 것으로 나타난 결과와 유사한 경향을 보였다.

\section{총 페놀성 화합물 함량 및 항산화 활성}

과열증기 처리한 양파 과육의 총 페놀성 화합물 함량과 항산화활성과 분석 결과는 Table 4에 나타내었다. 총 페놀 물질 함량의 경우 대조군은 $3.92 \mathrm{mg} \mathrm{GAE} / \mathrm{kg}$ 이었고, 처리군 은 $\mathrm{T} 100 \sim \mathrm{T} 300$ 에서 각각 $1.83,2.75,2.67,3.92,4.92 \mathrm{mg}$ $\mathrm{GAE} / \mathrm{kg}$ 으로 나타나 과열증기처리 온도가 증가할수록 높

Table 3. Volatile compounds of onion flesh treated by SHS at various temperature

\begin{tabular}{|c|c|c|c|c|c|c|}
\hline \multirow{2}{*}{ Volatile components } & \multirow{2}{*}{ Control } & \multicolumn{5}{|c|}{ SHS treatment condition } \\
\hline & & $\mathrm{T} 100$ & $\mathrm{~T} 150$ & $\mathrm{~T} 200$ & $\mathrm{~T} 250$ & T300 \\
\hline Methyl thiirane & $475.15 \pm 98.88^{1 / \mathrm{a} 2)}$ & $0.00 \pm 0.00^{\mathrm{b}}$ & $0.00 \pm 0.00^{b}$ & $0.00 \pm 0.00^{b}$ & $0.00 \pm 0.00^{b}$ & $0.00 \pm 0.00^{b}$ \\
\hline 1,1'-sulfinyl bis Propane & $193.42 \pm 23.38^{a}$ & $0.00 \pm 0.00^{\mathrm{b}}$ & $0.00 \pm 0.00^{b}$ & $0.00 \pm 0.00^{b}$ & $0.00 \pm 0.00^{\mathrm{b}}$ & $0.00 \pm 0.00^{\mathrm{b}}$ \\
\hline Methyl propenyl disulfide & $153.90 \pm 27.75^{\mathrm{a}}$ & $3.71 \pm 4.46^{b}$ & $3.95 \pm 5.58^{b}$ & $11.31 \pm 6.36^{b}$ & $1.75 \pm 3.04^{b}$ & $10.62 \pm 5.30^{b}$ \\
\hline Dimethyl trisulfide & $30.57 \pm 29.32^{\mathrm{a}}$ & $2.04 \pm 2.32^{\mathrm{b}}$ & $33.95 \pm 8.58^{\mathrm{a}}$ & $27.62 \pm 4.54^{\mathrm{a}}$ & $0.00 \pm 0.00^{\mathrm{b}}$ & $5.36 \pm 2.33^{\mathrm{b}}$ \\
\hline 1,5-Dithiocane & $1,179.51 \pm 92.29^{9}$ & $2.60 \pm 2.25^{\mathrm{f}}$ & $99.14 \pm 20.82^{\mathrm{a}}$ & $84.20 \pm 29.85^{b}$ & $25.63 \pm 7.31^{\mathrm{e}}$ & $83.55 \pm 5.72^{c}$ \\
\hline Diallyl disulphide & $292.41 \pm 27.88^{\mathrm{a}}$ & $0.00 \pm 0.00^{\mathrm{b}}$ & $0.00 \pm 0.00^{\mathrm{b}}$ & $0.00 \pm 0.00^{\mathrm{b}}$ & $0.00 \pm 0.00^{\mathrm{b}}$ & $0.00 \pm 0.00^{\mathrm{b}}$ \\
\hline Methyl propyl trisulfide & $436.79 \pm 14.09^{b}$ & $0.51 \pm 0.89^{\mathrm{e}}$ & $132.08 \pm 26.53^{b}$ & $49.42 \pm 10.57^{\mathrm{cd}}$ & $12.97 \pm 11.27^{\circ}$ & $71.62 \pm 16.10^{c}$ \\
\hline 1-(methylthio) 1-Propene & $281.69 \pm 39.05^{\mathrm{a}}$ & $0.00 \pm 0.00^{\mathrm{c}}$ & $4.43 \pm 7.67^{\mathrm{c}}$ & $193.07 \pm 7.69^{\mathrm{b}}$ & $0.00 \pm 0.00^{\mathrm{c}}$ & $27.59 \pm 20.07^{\mathrm{c}}$ \\
\hline Dimethyl tetrasulphide & $184.04 \pm 141.06^{1) \mathrm{a}}$ & $0.00 \pm 0.00^{\mathrm{b}}$ & $65.66 \pm 12.77^{\mathrm{b}}$ & $10.32 \pm 1.94^{\mathrm{b}}$ & $0.00 \pm 0.00^{\mathrm{b}}$ & $5.94 \pm 5.91^{\mathrm{b}}$ \\
\hline Dipropyl Trisulfide & $2,358.92 \pm 52.45^{\mathrm{g}}$ & $15.03 \pm 6.48^{\mathrm{f}}$ & $102.74 \pm 47.24^{c}$ & $24.088 \pm 10.36^{\mathrm{e}}$ & $52.02 \pm 20.74^{d}$ & $229.37 \pm 0.38^{\mathrm{b}}$ \\
\hline 3,5-Diethyl 1,2,4-Trithiolane & $3,264.95 \pm 87.17^{\mathrm{c}}$ & $51.98 \pm 20.07^{\mathrm{c}}$ & $466.91 \pm 146.54^{a}$ & $207.22 \pm 97.13^{b}$ & $113.12 \pm 35.33^{\mathrm{bc}}$ & $162.55 \pm 167.60^{c}$ \\
\hline 1,1'-thiobis-1-Propene & $206.36 \pm 322.07^{\mathrm{a}}$ & $0.00 \pm 0.00^{\mathrm{a}}$ & $0.00 \pm 0.00^{\mathrm{a}}$ & $0.00 \pm 0.00^{\mathrm{a}}$ & $0.00 \pm 0.00^{\mathrm{a}}$ & $0.00 \pm 0.00^{\mathrm{a}}$ \\
\hline 1,3-Propanedithiol & $1,133.11 \pm 1940.98^{\mathrm{a}}$ & $3.08 \pm 5.33^{\mathrm{a}}$ & $0.00 \pm 0.00^{\mathrm{a}}$ & $12.29 \pm 21.28^{\mathrm{a}}$ & $0.00 \pm 0.00^{\mathrm{a}}$ & $0.11 \pm 0.19^{\mathrm{a}}$ \\
\hline Diallyl disulfide & $6.96 \pm 7.71^{\mathrm{a}}$ & $0.18 \pm 0.32^{\mathrm{b}}$ & $5.34 \pm 0.20^{\mathrm{ab}}$ & $3.48 \pm 0.60^{\mathrm{ab}}$ & $0.00 \pm 0.00^{b}$ & $0.89 \pm 1.54^{\mathrm{ab}}$ \\
\hline
\end{tabular}

${ }^{1)}$ All measurements were performed in triplicate. Data was expressed as mean $\pm \mathrm{SD}$.

${ }^{2) a-g}$ Different superscript in the same raw are significantly different by Duncan's multiple range test at $\mathrm{p}<0.05$.

Table 4. Antioxidant activities of onion flesh treated by SHS at various temperature

\begin{tabular}{|c|c|c|c|c|c|}
\hline \multirow{2}{*}{\multicolumn{2}{|c|}{ Type }} & \multicolumn{3}{|c|}{ Antioxidant activities } & \multirow{2}{*}{$-\begin{array}{c}\mathrm{TPC} \\
\text { (mg of } \mathrm{GAE} / \mathrm{kg} \text { ) }\end{array}$} \\
\hline & & DPPH (\%) & ABTS (\%) & $\begin{array}{c}\text { FRAP } \\
\text { (Absorbance) }\end{array}$ & \\
\hline \multicolumn{2}{|c|}{ Control } & $37.85 \pm 0.12^{\mathrm{e}}$ & $3.99 \pm 0.62^{\mathrm{a}}$ & $0.06 \pm 0.01^{\mathrm{a}}$ & $3.92 \pm 0.63^{\mathrm{a}}$ \\
\hline \multirow{5}{*}{$\begin{array}{c}\mathrm{SHS} \\
\text { treatment }\end{array}$} & $\mathrm{T} 100$ & $39.23 \pm 0.52^{\mathrm{d}}$ & $4.34 \pm 0.35^{\mathrm{a}}$ & $0.06 \pm 0.00^{\mathrm{ab}}$ & $1.83 \pm 0.29^{\mathrm{d}}$ \\
\hline & $\mathrm{T} 150$ & $38.99 \pm 0.20^{\mathrm{d}}$ & $4.38 \pm 0.20^{\mathrm{a}}$ & $0.06 \pm 0.00^{\mathrm{ab}}$ & $2.75 \pm 0.25^{\mathrm{c}}$ \\
\hline & $\mathrm{T} 200$ & $43.23 \pm 0.10^{b}$ & $3.77 \pm 1.44^{\mathrm{a}}$ & $0.06 \pm 0.00^{\mathrm{ab}}$ & $2.67 \pm 0.38^{c}$ \\
\hline & $\mathrm{T} 250$ & $45.12 \pm 0.12^{\mathrm{a}}$ & $3.86 \pm 0.08^{\mathrm{a}}$ & $0.05 \pm 0.00^{\mathrm{ab}}$ & $3.92 \pm 0.94^{b}$ \\
\hline & $\mathrm{T} 300$ & $41.45 \pm 0.15^{\mathrm{c}}$ & $4.49 \pm 0.13^{\mathrm{a}}$ & $0.05 \pm 0.01^{\mathrm{ab}}$ & $4.92 \pm 1.56^{\mathrm{a}}$ \\
\hline
\end{tabular}

게 나타났다. 하지만, 과열증기처리 시 $\mathrm{T} 100$ 에서 $\mathrm{T} 200$ 까지 는 대조군에 비해 다소 감소하는 결과를 보였지만, T250 T300에서는 처리 온도가 높아질수록 대조구에 비해 오히려 증가하는 경향을 보였다.

$\mathrm{DPPH}$ 라디칼 소거능에서는 대조구가 $37.85 \%$ 로 나타났 고, T100 T300 각각 약 $39.23,38.99,43.23,45.12,41.45 \%$ 로 나타나 전체적으로 과열증기처리 따라 대조구에 비해 증가 함을 알 수 있었다. T250까지는 과열증기처리 온도가 높아 질수록 증가하였지만, $\mathrm{T} 300$ 에서는 다소 감소하는 것으로 나타났다. 그런데, 가장 높은 처리 온도인 $\mathrm{T} 300$ 조건에서 총 페놀화합물의 경우에는 T100 250 조건에 비해 증가하 
는 결과를 보였다. 이러한 결과는 일반적으로 총 페놀성 화합물 함량과 DPPH 라디칼 소거능은 양의 상관관계를 나타내는 경향과는 다소 상충되는 결과로 보인다. 이러한 결과는 DPPH 라디칼 소거능에 영향을 미치는 총 페놀성 화합물 이외의 물질의 감소 때문인 것으로 판단되며 이에 대한 보완 연구가 필요할 것으로 판단된다. ABTS 라디칼 소거능의 경우 대조구에서 약 $4 \%$ 였고, $\mathrm{T} 100$ 에서 $\mathrm{T} 300$ 까지 3.37 4.49\%로 나타나 과열증기처리에 따라 다소 증가하였 지만, 활성 자체가 전체적으로 낮게 나타났다. ABTS 라디 컬 소거능과 DPPH 라디컬 소거능은 같은 소거능 활성이지 만 값은 다르게 나타나는데, $\mathrm{ABTS}+$-는 지용성, 친수성 물 질 모두에 용해되어 소수성, 친수성 물질의 라디칼 소거 활성을 모두 측정 가능한 반면에, DPPH는 지용성 물질에만 용해되어 친수성 물질의 라디칼 소거 활성을 알아보는 데에 는 다소 제한이 있기도하지만(28), 본 연구에서는 양파 과육 자체의 항산화 활성을 측정하였기 때문에 결과 수치가 다소 낮게 나타난 것으로 판단된다. FRAP 활성의 경우 또한 대 조구와 처리구의 차이는 보이지 않았다.

\section{$\mathrm{pH}$, Brix 및 수분 함량}

과열증기 처리에 따른 양파의 $\mathrm{pH}$, Brix 및 수분함량 측정 결과는 Table 5에 나타내었다. 기본적인 품질지표인 $\mathrm{pH}$,

Table 5. pH, Brix, moisture of onion flesh treated by SHS at various temperature

\begin{tabular}{|c|c|c|c|c|}
\hline & & $\mathrm{pH}$ & Brix & moisture $(\%)$ \\
\hline \multicolumn{2}{|c|}{ Control } & $5.29 \pm 0.01^{1) 22}$ & $9.00 \pm 0.00^{b}$ & $91.66 \pm 0.09^{b}$ \\
\hline \multirow{5}{*}{$\begin{array}{c}\text { SHS } \\
\text { treatment }\end{array}$} & $\mathrm{T} 100$ & $5.65 \pm 0.00^{\mathrm{a}}$ & $9.20 \pm 0.00^{\mathrm{a}}$ & $93.41 \pm 0.25^{\mathrm{a}}$ \\
\hline & $\mathrm{T} 150$ & $5.57 \pm 0.01^{\mathrm{d}}$ & $9.00 \pm 0.00^{b}$ & $93.15 \pm 1.21^{\mathrm{a}}$ \\
\hline & $\mathrm{T} 200$ & $5.64 \pm 0.00^{b}$ & $9.00 \pm 0.00^{b}$ & $93.14 \pm 0.38^{\mathrm{a}}$ \\
\hline & $\mathrm{T} 250$ & $5.65 \pm 0.01^{\mathrm{a}}$ & $9.00 \pm 0.00^{b}$ & $93.25 \pm 0.21^{\mathrm{a}}$ \\
\hline & $\mathrm{T} 300$ & $5.64 \pm 0.01^{b}$ & $9.00 \pm 0.00^{b}$ & $93.22 \pm 0.47^{\mathrm{a}}$ \\
\hline
\end{tabular}

${ }^{1)}$ All measurements were performed in triplicate. Data was expressed as mean \pm SD.

2akb Different superscript in the same raw are significantly different by Duncan's multiple range test at $\mathrm{p}<0.05$.
Brix, 수분함량은 과열증기처리에 의해 큰 변화는 보이지 않았고, 양파 과육 고유의 특성을 유지하는 것을 알 수 있었 다. $\mathrm{pH}$ 의 경우 과열증기처리에 의해 5.29(비처리 대조군)에 서 약 5.56 5.65로 미미한 증가를 보였고, 처리 조건에 따른 차이는 거의 없었다. Brix는 대조군이 9.0 이고, 처리에 따라 8.8 9.2 범위로 나타나 확연한 증감은 보이지 않았다. 수분 함량은 $\mathrm{pH}$ 와 유사하게 처리에 의해 전체적으로 증가하는 경향을 보였고, 처리 온도 증가에 따른 차이는 거의 미미한 수준이었다. 한편, 과열증기 적용 시 처리 온도 및 시간 등의 차이에 따라 시료의 건조가 이루어지기도 하지만 (29-31), 본 연구에서는 양파 시료가 과열 증기가 지니는 수분을 일부 흡수하게 되어 결과적으로 수분 함량이 증가한 것으로 사료된다.

조직감

과열증기처리에 따른 양파의 조직감 측정결과는 Table 6에 나타내었다. 과열증기 처리에 따라 hardness, chewiness 는 급격하게 감소하며 대조구와 유의적 차이를 나타내었 다. Maria 등(33)에서 가열처리 온도 $50 \sim 60^{\circ} \mathrm{C}$ 사이에서 양파 세포의 팽창력의 손실의 결과로 경도에 급격한 감소가 일어 난다는 보고가 있었고, 내부온도 $130^{\circ} \mathrm{C}$ 와 스팀온도 $100^{\circ} \mathrm{C}$ 이상에서 가열처리를 한 본 실험에서도 같은 이유로 hardness가 급격히 감소했을 것으로 예상된다. springiness 와 resilience의 경우 과열증기처리 조건에 따른 뚜렷한 증감 의 경향을 보이지 않았고, gumminess와 cohesiveness는 처 리구와 대조구가 유의적 차이가 없는 것을 확인하였다 $(\mathrm{p}<0.05)$.

\section{양파 열수추출액의 총 가용성 고형분 함량}

양파 열수추출액의 총 가용성 고형분 함량은 Fig. 2에 나타내었다. 양파를 이용한 식품, 특히 음료, 페이스트 등 액상제품의 경우, 제조 시 용매에 용해되는 가용성 성분만 이 체내 흡수가 가능하기 때문에 양파 추출액의 총 가용성 고형분 함량은 양파 가공 및 소재화를 위한 중요한 기초자 료로 사용될 수 있다. $40,70,90^{\circ} \mathrm{C}$ 의 온도에서 각각 추출하

Table 6. Textural attributes of onion flesh treated by SHS at various temperature

\begin{tabular}{|c|c|c|c|c|c|c|c|}
\hline \multirow{2}{*}{\multicolumn{2}{|c|}{ Type }} & \multicolumn{6}{|c|}{ Texture profile attribute (TPA) } \\
\hline & & Hardness & Springiness & Chewiness & Gumminess & Cohesiveness & Resilience \\
\hline \multicolumn{2}{|c|}{ Control } & $2,686.66 \pm 1,543.03^{1 \mathrm{la} 2)}$ & $2.97 \pm 3.38^{b}$ & $4,462.54 \pm 4811.06^{\mathrm{a}}$ & $1,848.44 \pm 1225.31^{\mathrm{a}}$ & $0.70 \pm 0.12^{\mathrm{a}}$ & $0.72 \pm 0.26^{b}$ \\
\hline \multirow{5}{*}{$\begin{array}{l}\text { SHS } \\
\text { treatment }\end{array}$} & $\mathrm{T} 100$ & $540.58 \pm 643.24^{\mathrm{a}}$ & $1.85 \pm 3.05^{\mathrm{b}}$ & $477.28 \pm 483.68^{\mathrm{b}}$ & $1,367.89 \pm 1775.20^{\mathrm{a}}$ & $0.71 \pm 0.16^{\mathrm{a}}$ & $1.01 \pm 0.48^{\mathrm{ab}}$ \\
\hline & $\mathrm{T} 150$ & $384.22 \pm 256.84^{\mathrm{ab}}$ & $1.47 \pm 2.34^{b}$ & $510.25 \pm 485.05^{\mathrm{b}}$ & $1,185.58 \pm 1355.08^{a}$ & $0.72 \pm 0.07^{\mathrm{a}}$ & $1.26 \pm 0.44^{\mathrm{a}}$ \\
\hline & $\mathrm{T} 200$ & $211.25 \pm 356.72^{\mathrm{b}}$ & $4.54 \pm 4.03^{\mathrm{ab}}$ & $481.16 \pm 307.56^{b}$ & $1,031.99 \pm 1581.62^{\mathrm{a}}$ & $0.75 \pm 0.14^{\mathrm{a}}$ & $1.00 \pm 0.43^{\mathrm{ab}}$ \\
\hline & $\mathrm{T} 250$ & $316.81 \pm 449.23^{\mathrm{b}}$ & $4.64 \pm 4.31^{\mathrm{ab}}$ & $464.74 \pm 215.91^{\mathrm{b}}$ & $1,128.15 \pm 1688.61^{\mathrm{a}}$ & $0.82 \pm 0.23^{\mathrm{a}}$ & $1.01 \pm 0.44^{\mathrm{ab}}$ \\
\hline & $\mathrm{T} 300$ & $146.33 \pm 100.14^{\mathrm{b}}$ & $3.77 \pm 3.92^{\mathrm{ab}}$ & $558.62 \pm 275.44^{\mathrm{b}}$ & $1,210.93 \pm 1273.80^{\mathrm{a}}$ & $0.72 \pm 0.08^{\mathrm{a}}$ & $1.10 \pm 0.45^{\mathrm{ab}}$ \\
\hline
\end{tabular}

${ }^{1)} \mathrm{All}$ measurements were performed in triplicate. Data was expressed as mean $\pm \mathrm{SD}$.

2)abb Different superscript in the same raw are significantly different by Duncan's multiple range test at $p<0.05$. 
여 총 가용성 고형분 함량을 비교하였다. 전체적으로 대조 구에 비해 과열증기처리군의 가용성 고형분 함량이 높은 것으로 나타났다. 비처리구인 control은 침출조건 $40^{\circ} \mathrm{C}$ 에서 30 초 침출 시 $0.365 \%$ 에서 120 분 침출 시 $1.211 \%$ 로 가용성 고형분이 거의 용출되지 않았고, $70,90^{\circ} \mathrm{C}$ 에서 120 분 침출 시 각 $4.675 \%, 4.576 \%$ 로 나타난데 비해, T100과 T200 처리 군에서는 $40^{\circ} \mathrm{C}$ 에서도 $5 \%$ 이상으로 나타났고, 추출온도 및 시간이 높아짐에 따라 증가하여 $20 \%$ 이상으로 나타났다. 결과적으로 양파의 열수에 의한 추출 시 추출액의 고형분
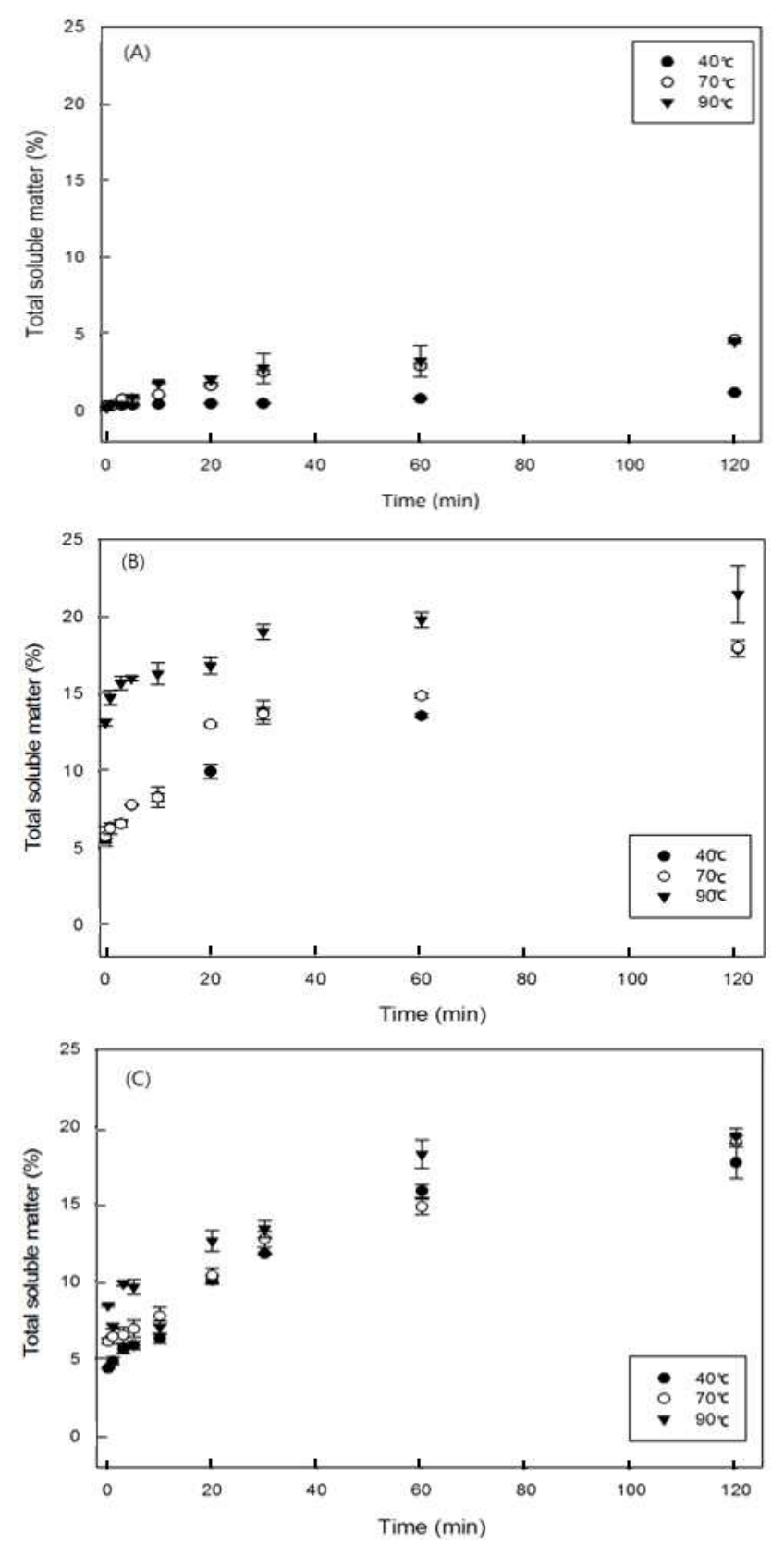

Fig. 2. The effect of SHS treatment on total soluble matters of onion flesh in hot water at various temperature $\left(40,70,90^{\circ} \mathrm{C}\right)$ as a function of time.

A, Control; B, T100; C, T200
함량이 과열증기 처리에 따라 증가한 것은 매우 흥미로운 결과로 이는 처리에 의한 양파 과육 내 조직 변화 등을 통해 양파가 지니는 고형분의 용출이 유리해진 결과로 사료 된다. 과열증기의 적용에 따른 시료의 추출 수율과 관련해 서는 과열증기 추출 시 증기 온도가 높아질수록 검정 후추 와 타임의 정유 성분의 추출수율이 증가하였다는 보고(34) 가 있다. 그리고, 과열증기 처리군에서 열수 추출액의 고형 분 함량이 높아진 것으로 나타난 결과는 처리에 따른 수분 감소로 인하여 대조군에 비해 상대적으로 처리군 시료의 고형분 중량이 증가한 때문은 아닌 것으로 판단된다. 본 연구의 수분함량 측정 결과(Table 5)에 나타난 바와 같이, $91.66 \%$ 로 나타난 비처리 양파 대조군에 비해 과열증기 처 리군의 수분함량이 93.14 93.41\%로 오히려 높게 나타났고, 본 결과는 처리에 따라 양파 과육이 과열 증기가 지니는 수분을 일부 흡수하고, 결과적으로 양파 자체가 지니는 고 형분 함량 비율은 감소했다는 것을 나타내기 때문이다. 양 파를 이용하여 음료 등으로 가공할 경우 과열증기 처리를 통해 양파의 가용성 물질의 용출률을 효과적으로 높일 수 있을 것으로 판단된다.

\section{관능적 특성}

과열증기처리 양파의 관능평가는 Table 7에 나타내었다. 매운맛이 많이 나고, 이에 대한 선호도가 낮을수록 spicy 항목에 낮은 점수를 부여하게 하고, 외관(appearance)은 관 능적으로 보기 좋은 것에 높은 점수를 부여하게 하고, 향 (flavor)는 양파의 불쾌취를 포함한 전체적인 향에 대한 선 호도가 높을수록 높은 점수를 부여하였다. Texture는 섭취 시 조직감에 대한 선호도가 높을수록 높은 점수를 부여하도 록 하였고, 전체적인 기호도를 평가하였다. Spicy의 경우 과열증기처리에 따라 모든 조건에서 대조군에 비해 높은 점수를 보였다. 외관(appearance)는 대조군과 과열증기처 리군 사이의 유의적 차이가 나타나지 않았다. Flavor, texture, overall acceptability 부문에서는 과열증기처리군이 대조군에 비해 전제적으로 높은 점수를 보였다. 특히 spicy, flavor는 Table 4에 나타난 thiosulfinate, pyruvic acid 값의

Table 7. Evaluation of sensory characteristics of onion flesh treated by SHS at various temperature

\begin{tabular}{|c|c|c|c|c|c|c|}
\hline & & Spicy & pearance & lavor & Texture & $\begin{array}{c}\text { Overall } \\
\text { acceptability }\end{array}$ \\
\hline \multicolumn{2}{|c|}{ Control } & & & & & \\
\hline \multirow{5}{*}{$\begin{array}{l}\text { SHS } \\
\text { treatment }\end{array}$} & T100 & $5.69 \pm 2.59^{\mathrm{a}}$ & 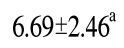 & $0^{\mathrm{a}}$ & & \\
\hline & $\mathrm{T} 150$ & $5.62 \pm 2.50^{\mathrm{a}}$ & $5.92 \pm$ & $5.08 \pm 1.98^{\mathrm{ab}}$ & 5.08 & $5.23 \pm 2.35^{\mathrm{ab}}$ \\
\hline & Т200 & $5.62 \pm 2.66^{\mathrm{a}}$ & $6.92 \pm 1.89^{\mathrm{a}}$ & $5.92 \pm 1.61^{\mathrm{a}}$ & $4.92 \pm 1.50^{\mathrm{a}}$ & $6.15 \pm 1.57^{\mathrm{a}}$ \\
\hline & $\mathrm{T} 250$ & $5.62 \pm 2.66^{\mathrm{a}}$ & $5.77 \pm 2.46^{\mathrm{a}}$ & $5.62 \pm 2.50^{\mathrm{a}}$ & $5.00 \pm 1.87^{\mathrm{a}}$ & $5.31 \pm 1.97^{\mathrm{ab}}$ \\
\hline & $\mathrm{T} 300$ & $6.23 \pm 2.83^{\mathrm{a}}$ & $6.46 \pm 1.98^{\mathrm{a}}$ & $6.15 \pm 1.91^{\mathrm{a}}$ & $5.15 \pm 1.28^{\mathrm{a}}$ & $6.15 \pm 1.95^{\mathrm{a}}$ \\
\hline
\end{tabular}

${ }^{15}$ All measurements were performed in triplicate. Data was expressed as mean \pm SD. 2)add Different superscript in the same raw are significantly different by Duncan's multiple range test at $\mathrm{p}<0.05$. 
경향과 유사함을 확인할 수 있었고, 결과적으로 과열증기 처리가 양파의 불쾌취를 효과적으로 저감화할 수 있을 것으 로 판단된다.

\section{요 약}

본 연구는 과열증기처리 기술을 양파에 적용하여 불쾌취 를 저감화하고, 이를 통해 고품질 양파 가공품 개발 및 소재 화에 활용하기 위한 기초 자료를 확보하고자 과열증기처리 에 따른 양파의 휘발성 물질, 불쾌취 유발 물질과 항산화활 성, 조직감, 관능적 특성 등 품질특성을 분석하였다. 과열증 기처리에 의해 휘발성 향기성분 및 불쾌취와 매운맛의 지표 물질이 저감화됨을 확인하였다. 항산화활성 및 총 페놀성 화합물 함량은 다소 증가하는 경향을 보였으며, hardness, chewiness 등은 확연하게 감소하는 것으로 나타났다. 양파 추출액의 총 가용성 고형분 함량은 처리에 의해 전체적으로 증가하였으며 처리에 따라 기호도 점수가 높아지는것을 확인하였다. 결과적으로 과열증기 처리가 양파의 불쾌취 저감화에 효과적임을 확인할 수 있었다. 본 연구결과는 과 열증기 기술을 적용한 양파의 불쾌취 저감화 및 이를 통한 다양한 고품질 가공품 개발 및 소재화를 위한 중요한 기초 자료로 활용될 수 있으리라 판단되며, 과열증기오븐 처리 를 통해 불쾌취를 조절함과 동시에 생리활성능을 지니는 향기 성분 및 유용성분의 감소는 최소화하는 추가적인 연구 가 필요할 것으로 사료된다.

\section{감사의 글}

본 논문은 농림축산식품부 고부가가치식품개발사업 (113023-03-3-HD020) 지원에 의하여 수행되었으며, 이에 감사드립니다.

\section{References}

1. Ra KS, Suh HJ, Chung SH, Son JY (1997) Antioxidant activity of solvent extract from onion skin. Korean J Food Sci Technol, 29, 595-600

2. Kim MY, Chun SS (2001) Effects of onions on the quality characteristics of strawbery jam. Korean J Soc Food Cookery Sci, 17, 316-322

3. Miean KH, Mohamed S (2001) Flavonoid (myricetin, quercetin, kaempferol, luteolin, and apigenin) content of edible tropical plants. J Agric Food Chem, 49, 3106-3112

4. Jeon SY, Jeong EJ, Baek JH, Cha YJ (2011) Analytical method validation of quercetin in Changnyeong onion extract as a functional ingredient for functional health food. J Korean Soc Food Sci Nutr, 40, 565-569

5. Sheo HJ, Lim HJ, Jung DL (1993) Effects of onion juice on toxicity of lead in rat. J Korean Soc Food Nutr, 22, 138-143

6. Hou WN, Go EK (2004) Extractive optimization of functional components for processing of onion health promotion drink. Korean J Food Sci Technol, 36, 403-409

7. Ramos FA, Takaishi Y, Shirotori M, Kawaguchi Y, Tsuchiya K, Shibata H, Higuti T, Tadokoro T, Takeuchi M (2006) Antibacterial and antioxidant activities of quercetin oxidation products from yellow onion (Allium cepa) skin. J Agric Food Chem, 54, 3551-3557

8. Azuma K, Minami Y, Ippoushi K, Terao J (2007) Lowering effects of onion intake in oxidative stress biomarkers in streptozotocin-induced diabetic rats. J Clin Biochem Nutr, 40, 131-140

9. Chung HK, Shin MJ, Cha YJ, Lee KH (2011) Effect of onion peel extracts on blood lipid profile and blood coagulation in high fat fed SD rat. Korean J Food Nutr, 24, 442-450

10. Song HP, Shim SL, Jung IS, Kim DH, Kim KS (2009) Analysis of volatile organosulfur compounds in Korean Allium Species. Korean J Food Preserv, 16, 929-937

11. Park ER, Ko CN, Kim SH, Kim KS (2001) Analysis of volatile organic components from fresh and decayed onions. J Korean Soc Food Sci Nutr, 30, 1011-1020

12. Kee HJ, Park YK (1999) Effect of seaweeds and absorbents on volatile flavor components of onion juice. Korean J Food Sci Technol, 31, 1477-1483

13. Choi Y, Oh JH, Bae IY, Cho Ek, Kwon DJ, Park HW, Yoon S (2013) Changes in quality characteristics of seasoned soy sauce treated with superheated steam and high hydrostatic pressure during cold storage. Korean J Food Cook Sci, 29, 387-398

14. Kim OS, Lee DH, Chun WP (2008) Eco-friendly drying technology using superheated steam. Korean Chem Eng Res, 46, 258-273

15. Idrus NFM, Yang TA (2012) Comparison between roasting by superheated steam by convection on changes in colour, texture and microstructure of peanut (Arachis hypogaea). Food Sci Technol Res, 18, 515-524

16. Sila DN, Smout C, Vu ST, Loey AV, Hendrickx M (2005) Influence of pretreatment conditions on the texture and cell wall components of carrots during thermal processing. J Food Sci, 70, 85-91 
17. Kim IS, Jang AR, Jin SK, Lee MH, Jo C (2008) Effect of marination with mixed salt and kiwi juice and cooking methods on the quality of pork loin-based processed meat product. J Korean Soc Food Sci Nutr, 37, 217-222

18. Karimi F (2010) Application of superheated steam for the drying of food products. Int Agrophysics, 24, 195-204

19. Kim CW, Lee ET, Cha YL, Choi IH, Hwang EJ, Park KG (2012) Evaluation of yellowish skin color ('chartreus') onion lines for soluble solid content and sugar characteristics. Korean J Breed Sci, 44, 510-515

20. Benzie IFF, Strain JJ (1996) The ferric reducing ability of plasma (FRAP) as s measure of "Antioxidant power": The FRAP assay. Anal Biochem, 239, 70-76

21. Biglari F, AIKarkhi AFM, Easa AM (2008) Antioxidant activity and phenolic content of various date palm (Phoenix dactylifera) fruits from Iran. Food Chem, 107, 1636-1641

22. Choi JS, Lee JH, Park HJ, Kim HG, Young HS, Mun SI (1993) Screening for antioxidant activity of plants and marine algae and it's active principle from Prunus davidiana. Korean J Pharmacogn, 24, 299-303

23. Kim DO, Jeong SW, Lee CY (2003) Antioxidant capacity of phenolic phytochemicals from various cultivars of plums. Food Chem, 81, 321-326

24. Kim BC, Kang SW, Jung CH, Heo HJ, Lee SC, Cho SH, Choi SG (2010) Influence of ultrasonification on extraction yield and chemical properties of green tea infusion. Agric Life Sci, 44, 91-99

25. Lee HY, Jeong EJ, Jeon SY, Cho MS, Cho WJ, Kim HD, Cha YJ (2008) Comparison of volatile flavor compounds of domestic onions harvested in various regions. J Korean Soc Food Sci Nutr, 37, 1609-1614
26. Li C, Schmidt NE, Gitaitis R (2011) Detection of onion postharvest diseases by analyses of headspace volatiles using a gas sensor array and GC-MS. Food Sci Technol, 44, 1019-1025

27. Kim HS, Kim MH (2009) Browning and pungent taste reduction techniques in onion extract. Food Eng Prog, $13,360-364$

28. Arnao MB (2000) Some methodological problems in the determination of antioxidant activity using chromogen radicals : a practical case. Trends Food Sci Techol, 11, $419-421$

29. Svensson C (1985) Industrial application for new steam drying process in forest and agricultural industry. Proc. 4th Int. Drying Symp., May 5-8, Kyoto, Japan

30. Tang $Z$ (2002) Modeling the drying of spent grains in superheated steam. Ph D Thesis, University of Manitoba, Canada, p 1-177

31. Woods B, Musain H, Mujumdar AS (1994) Technoeconomic assessment of potential superheated steam drying applications in Canada. CEA Report9038U888

32. Yoo KS, Pike LM (2001) Determination of background pyruvic acid concentrations in onions, Allium species, and other vegetables. Sci Hortic, 89, 249-256

33. Gonzalez ME, Anthon GE, Barett DM (2010) Onion cells after high pressure and thermal processing: comparison of membrane integrity changes using different analytical methods and impact on tissue texture. J Food Sci, 75, 426-432

34. Rouatbi M, Duquenoy A, Giampaoli P (2007) Extraction of the essential oil of thyme and black pepper by superheated steam. J Food Eng, 78, 708-714 